Jurnal Visionida, Volume 4 Nomor 1 Juni 2018

\title{
PENGARUH PROMOSI PENJUALAN, PERIKLANAN DAN PENJUALAN PERSONAL TERHADAP KEPUTUSAN KONSUMEN MENGINAP DI GRAND CEMPAKA RESORT AND CONVENTION CIPAYUNG-BOGOR
}

\author{
THE EFFECT OF SALES PROMOTION, ADVERTISING AND PERSONAL SALES \\ TO CONSUMER DECISION STAY \\ AT GRAND CEMPAKA RESORT AND CONVENTION CIPAYUNG-BOGOR
}

\author{
Syifa Bunga Nurani ${ }^{1)}$; Lucky Hikmat Maulana ${ }^{2)}$ \\ Program Management Studies Faculty of Economic, University of Djuanda Bogor \\ Email : syifa.bunga.nurani@unida.ac.id
}

\begin{abstract}
The purpose of this study was to determine the influence of sales promotion, advertising and personal sales of consumer decision. This study was conducted at Grand Cempaka Resort and Convention Cipayung-Bogor. The study population was 12.785 customers and the samples are 100 people were selected by using random sampling. Data collection for variable studied using questionnaires. Data analysis used multiple linear regression. The result of test show that sales, promotion, advertising and personal sales simultaneously and partially effect the consumer's decision to stay at Grand Cempaka Resort and Convention Cipayung-Bogor. The most dominant has positive and significant effect is sales promotion because it has a significantly greater value than advertising and personal sales.
\end{abstract}

Keywords : Sales Promotion, Advertising, Personal sales and Consumer Decision

\begin{abstract}
ABSTRAK
Tujuan dari penelitian ini adalah untuk mengetahui pengaruh promosi penjualan, periklanan dan penjualan personal terhadap keputusan konsumen. Penelitian dilaksanakan di Grand Cempaka Resort and Convention Cipayung-Bogor. Populasi penelitian berjumlah 12,785 dan responden yang dijadikan sampel berjumlah 100 orang yang ditentukan dengan teknik random samling. Data dikumpulkan dengan menggunakan angket. Teknik analisa dilakukan dengan regresi berganda. Hasil pengujian menunjukkan bahwa promosi penjualan, periklanan serta penjualan personal secara simultan mempunyai pengaruh terhadap keputusan konsumen untuk menginap di Grand Cempaka Resort and Convention Cipayung-Bogor. Faktor dominan yang memiliki pengaruh positif serta signifikan adalah promosi penjualan, karena nilai signifikannya lebih besar jika dikomparasikan dengan periklanan dan penjualan personal.
\end{abstract}

Kata Kunci : Promosi Penjualan, Periklanan, Penjualan Personal dan Keputusan Konsumen. 


\section{PENDAHULUAN}

Perkembangan jasa hotel di kota Bogor mengalami kemajuan pesat, dan Bogor merupakan kota yang banyak dikunjungi wisatawan, baik wisatawan dalam negeri maupun mancanegara. Berdasarkan informasi yang diperoleh dari dinas kebudayaan dan pariwisata kota Bogor tahun 2016. Bogor dikunjungi wisatawan mencapai 5,3 juta orang. Lokasi pariwisata yang banyak dikunjungi adalah kawasan Puncak dengan data kunjungan mencapai 174 juta orang pada tahun 2016 (Biro Pusat Statistik).

Grand Cempaka Resort and Convention merupakan hotel yang berlokasi di kawasan Puncak, Cipayung-Bogor dan sudah berdiri dari tahun 1982. Hotel ini dikenal dengan hotel berhawa sejuk dengan nuansa pegunungan sehingga sesuai untuk penyelenggaraan pertemuan seminar, rekreasi, diktat dll. Banyak fasilitas yang ditawarkan seperti restaurant, massage and spa, tempat pertemuan (meeting) dll. Berikut data tingkat hunian Grand Cempaka tahun 2016 adalah;

Tabel 1. Data Tingkat Hunian Tahun 2006

\begin{tabular}{cccc}
\hline No & Bulan & Tingkat Hunian & Target Hunian \\
\hline 1 & Januari & $15 \%$ & $49 \%$ \\
2 & Februari & $25 \%$ & $49 \%$ \\
3 & Maret & $42 \%$ & $49 \%$ \\
4 & April & $53 \%$ & $49 \%$ \\
5 & Mei & $23 \%$ & $49 \%$ \\
6 & Juni & $7 \%$ & $49 \%$ \\
7 & Juli & $26 \%$ & $49 \%$ \\
8 & Agustus & $21 \%$ & $49 \%$ \\
9 & September & $23 \%$ & $49 \%$ \\
10 & Oktober & $25 \%$ & $49 \%$ \\
11 & November & $30 \%$ & $49 \%$ \\
12 & Desember & $32 \%$ & $49 \%$ \\
Sumber & Grand Cempaka, 2017 &
\end{tabular}

Tabel 1 menunjukkan bahwa tingkat hunian di Grand Cempaka berfluktuatif dari bulan ke bulan dan hanya bulan april tingkat hunian melebihi target yakni sebesar 53\%, sedangkan bulan lainnya tidak mecapai target. Berdasarkan permasalahan tersebut, maka perlu untuk melakukan penelitian mengenai strategi bauran promosi agar
Grand Cempaka menjadi hotel pilihan konsumen untuk menginap.

\section{MATERI DAN METODE}

\section{Bauran Promosi}

Bauran promosi merupakan perpadanan/gabungan alat-alat promosi (periklanan, penjualan promosi, hubungan masyarakat dan penjualan personal) sebagai media komunikasi untuk menjalin hubungan dengan pelanggannya (Kotler\& Amstrong: 2009). Berikutnya menurut Darmesta (2002) berpendapat bauran promosi adalah kombinasi strategi dari variabel-variabel periklanan, penjualan personal serta alat-alat promosi lainnya, untuk mencapai tujuan pasarnya.

\section{Promosi Penjualan (Sales Promotion)}

Promosi penjualan yaitu pembayaran (intensif) jangka pendek perusahaan untuk meningkatkan volume pembelian dari konsumennya (Kotler \& Amstrong: 2009). Sedangkan menurut Tjiptono (2008) promosi penjualan yaitu penggunaan intensif sebagai media persuasi langsung untuk mendorong pembelian dan jumlah pembelian dari pelanggan.

Tujuan promosi di antaranya untuk meraih pelanggan baru, menstimulus pelanggan untuk membeli, memperkenalkan produk terbaru dan memotivasi pelanggan membeli lebih banyak.

Kegiatan-kegiatan promosi meliputi sampel, kupon, pengembalian tunai, harga khusus/pengurangan harga, premi, barang promosi/barang khusus iklan, penghargaan dukungan, kontes, undian, permainan, diskon, barang-barang gratis, uang pendorong, pameran dan kontes penjualan.

\section{Periklanan (Advertising)}

Definisi periklanan adalah penyajian promosi produk perusahaan oleh sponsor yang membutuhkan penyelesaian pembayaran (Tjiptono : 2008).

Tujuan dari iklan adalah untuk menciptakan kesadaran merek perusahaan, 
menciptakan kesukaan dan keseriusan untuk membeli dan menstimuli pembelian berulang dari pelanggan .

Kegiatan periklanan meliputi media cetak, elektronik, media di luar ruangan dan media lini bawah (Tjiptono : 2008).

\section{Penjualan Personal (Personal Selling)}

Penjualan personal adalah bentuk penyajian secara pribadi dari seorang wiraniaga dengan pelanggan (Koler\& Amstrong : 2009). Berikutnya Tjiptono (2008) berpendapat bahwa penjualan personal adalah bentuk komunikasi langsung/tatap muka dengan calon pembeli/pelanggan untuk membentuk suatu pemahaman terhadap produk perusahaan, sehingga calon pelanggan berkeinginan membelinya.

Tujuan dari penjualan personal adalah mencari pelanggan baru dengan tujuan mengkomunikasikan produk perusahaan .

Menurut Saladin (2003), terdapat beberapa kegiatan dalam melaksanakan penjualan personal yaitu : a) Field selling yaitu wiraniaga/penjual mendatangi konsumen secara langsung dari rumah kerumah atau dari perusahaan ke perusahaan; b) Retail selling yaitu wiraniaga/penjual yang melayani konsumen yang datang ke perusahaan; c) Executive selling yaitu hubungan dengan pimpinan perusahaan lain dan pemerintahan untuk tujuan melakukan penjualan.

Menurut Kotler \& Amstrong (2009), langkah langkah dalam melakukan penjualan personal adalah; 1). mengidentifikasikan pelanggan potensial; 2). mengunjungi pelanggan; 3). melakukan pendekatan; 4). presentasi/demonstrasi; 5). mengatasi keberatan selama demonstrasi; 6). menutup penjualan.

\section{Keputusan Konsumen}

Menurut Kotler \& Amstrong (2009) keputusan konsumen adalah memilih merek yang paling diminati.Keputusan konsumen adalah tahapan seorang pembeli dimulai dari tahap

pengenalan kebutuhan/keinginan, penggalian/mencari informasi, evaluasi pilihan alternative, keputusan membeli dan perilaku setelah pembelian.

Sedangkan Tjiptono

mengemukakan, keputusan konsumen merupakan hubungan yang melibatkan tindakan individu untuk mendapatkan dan menggunakan produk yang dibutuhkan.

\section{Kerangka Pemikiran}

Kerangka pemikiran memaparkan secara teoritis variabel-variabel penelitian tentang bagaimana pertautan teori-teori yang berhubungan dengan variabel yang diteliti.

Berdasarkan tinjauan pustaka dan tujuan penelitian maka kerangka pemikiran variabel-variabel yang memiliki pengaruh kepada keputusan konsumen dapat ditampilkan pada gambar berikut:

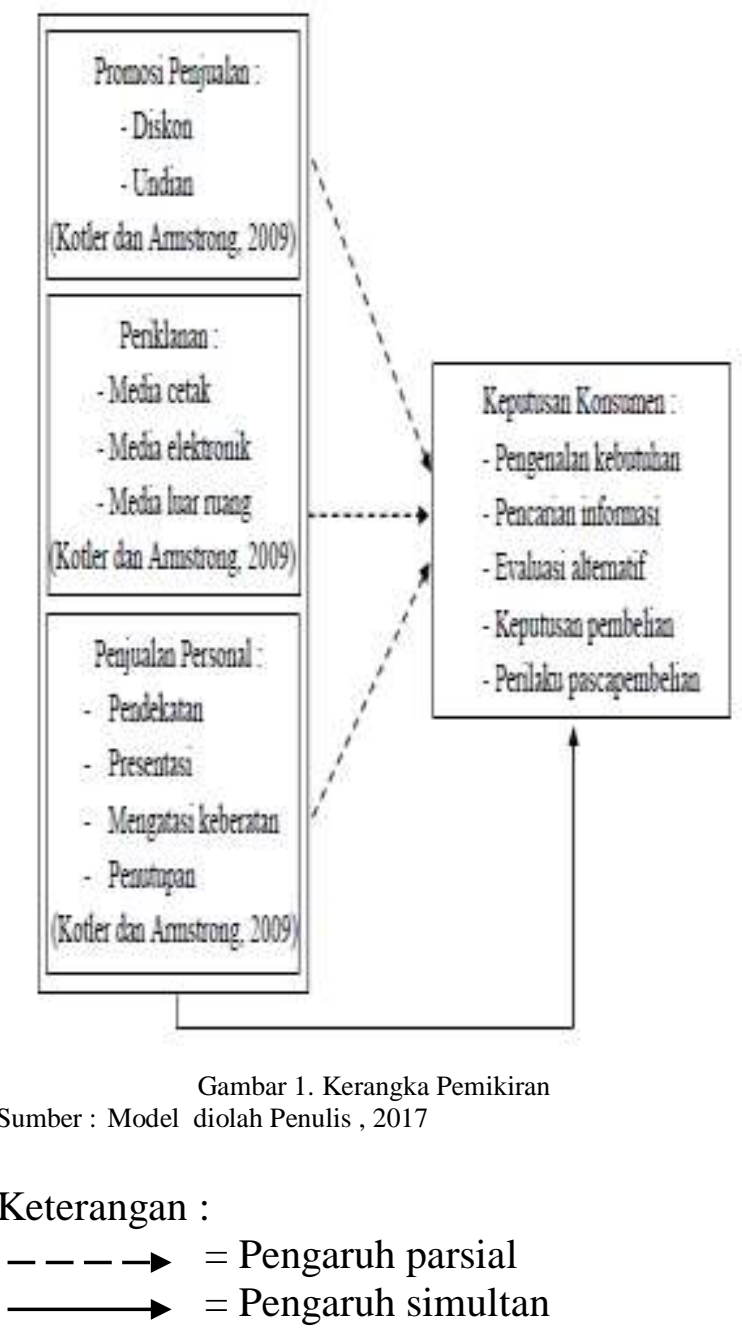


Pengaruh Promosi Penjualan Terhadap Keputusan konsumen

Manusia terbuka terhadap adanya rangsangan melalui panca indranya seperti sentuhan, suasana, aroma , rasa yang akan menimbulkan perhatian konsumen terhadap produk perusahaan. Promosi dapat membuat pelanggan berpikir tentang produk perusahaan. Promosi penjualan mampu merangsang dan membantu konsumen untuk membeli.

\section{Pengaruh Periklanan Terhadap Keputusan Konsumen}

Periklanan merupakan informasi perusahaaan kepada masyarakat tentang keberadaan produk perusahaan. Agar periklanan dapat dilakukan secara efektif maka perusahaan harus memperhatikan beberapa hal seperti pesan yang disampaikan, media yang digunakan, dan periklanan yang sesuai dengan biaya anggaran. Periklanan merupakan media perusahaan untuk menginformasikan kualitas dan karakteristik produk perusahaan untuk memotivasi pelanggan melaksanakan transaksi pembelian. Iklan memiliki peranan dalam menstimulus konsumen untuk mengikuti produk perusahaan.

\section{Pengaruh Penjualan Personal Terhadap Keputusan Konsumen}

Penjualan personal merupakan bentuk promosi pemasar kepada konsumen sasaran dengan tatap muka. Melalui tatap muka, pemasar dapat menyampaikan informasi sehingga membentuk suatu pemahaman mengenai produk perusahaan, sehingga konsumen terdorong untuk melakukan transaksi pembelian.

\section{Desain Penelitian}

Jenis penelitian bersifat kuantitatif dengan maksud membuktikan hipotesis yang sudah ditetap oleh peneliti. Penelitian menggunakan studi deskripsi untuk meneliti masalah-masalah factual saat ini dari populasi. Pemilihan sampel dilakukan secara acak/random. Data dikumpulkan melalui studi lapangan yaitu pengumpulan data melalui pengamatan langsung terhadap objek yang diteliti dengan penyebaran kuesioner tertutup dimana responden hanya memilih jawaban yang disediakan sesuai dengan pilihannya.

\section{Operasional Variabel}

Variabel adalah sifat/atribut dari objek/orang atau kegiatan yang bervariasi untuk dipelajari dan ditarik kesimpulan oleh peneliti. Variabel yang dianalisis meliputi variabel independen (X) yakni promosi penjualan, periklanan serta penjualan personel dan variabel dependen (Y) yaitu keputusan konsumen. Adapun variabel operasional dari penelitian ini adalah:

Tabel 2. Operasional Variabel

\begin{tabular}{|c|c|c|c|}
\hline Variabel & Kousep Variabel & Indikator & Skala \\
\hline $\begin{array}{l}\text { Promosi } \\
\text { Penjualan } \\
\left(\mathrm{X}_{\mathrm{I}}\right)\end{array}$ & $\begin{array}{l}\text { Promosi penjualan adalah } \\
\text { insentif jangha pendek untalk } \\
\text { menderong pembelan atau } \\
\text { penjualan produl atau jasa. } \\
\text { (Koter dan Armstrong, 2009) }\end{array}$ & $\begin{array}{l}\text { 1. Diskon } \\
\text { 2. Undian }\end{array}$ & $\begin{array}{l}\text { Ordinal } \\
\text { Linkert } \\
(1-5)\end{array}$ \\
\hline $\begin{array}{l}\text { Perklknan } \\
\text { (X.) }\end{array}$ & $\begin{array}{l}\text { Penillanan menupaban segala } \\
\text { bentuk presentasi dan promosi } \\
\text { gagasan, barang atau jasa yang } \\
\text { dibayar oleh sponsor yang } \\
\text { tendentifikasi (Tjpptono, 2008) }\end{array}$ & $\begin{array}{l}\text { 1. Media cetak } \\
\text { 2. Media elektroaik } \\
\text { 3. Medas lvar ruang }\end{array}$ & $\begin{array}{l}\text { Ordinal } \\
\text { Linkert } \\
(1-5)\end{array}$ \\
\hline $\begin{array}{l}\text { Penizalan } \\
\text { Perscaal } \\
\text { (X) }\end{array}$ & $\begin{array}{l}\text { Penjualan personal adalah } \\
\text { presentasi prbadr oleh wiraniaga } \\
\text { dengan tujuan melakukan } \\
\text { penjualan dan membangun } \\
\text { hubungan dengan pelanggan. } \\
\text { (Kodler dan Amstrong, 2009) }\end{array}$ & $\begin{array}{l}\text { 1. Pesdekatan } \\
\text { 2. Presentasi } \\
\text { 3. Mengatasi } \\
\text { keberatan } \\
\text { 4. Peuntupan }\end{array}$ & $\begin{array}{l}\text { Ordinal } \\
\text { Linkert } \\
(1-5)\end{array}$ \\
\hline $\begin{array}{l}\text { Keputuasan } \\
\text { Konsumen } \\
\text { (Y) }\end{array}$ & $\begin{array}{l}\text { Kepunusan lonsumen adalah } \\
\text { membeli merek yang paling } \\
\text { desulai, tetapi dua faktor bisa } \\
\text { berada antara niat pembelian dan } \\
\text { keputusan pembelian } \\
\text { (Kodler dan Amstrong, 2009) }\end{array}$ & $\begin{array}{l}\text { 1. Pengenalan } \\
\text { kebutuhan } \\
\text { 2. Pencanan } \\
\text { informasi } \\
\text { 3. Evaluasi } \\
\text { altematif } \\
\text { 4. Keputusan } \\
\text { pembelian } \\
\text { 5. Penlaku } \\
\text { Pascapembelian }\end{array}$ & $\begin{array}{c}\text { Ordinal } \\
\text { Lankert } \\
(1-5)\end{array}$ \\
\hline
\end{tabular}

Sumber : Data Diolah , 2017

\section{Pengambilan Sampel}

Populasi penelitian adalah objek konsumen yang sedang menginap di lokasi penelitian tahun 2016 sebanyak 12,785 
orang. Dengan menggunakan rumus dari Slovin didapat 100 sampel yang dilakukan secara acak/random.

\section{Uji Validitas}

Yaitu untuk menguji pernyataan dalam kuesioner, mengungkapkan sesuatu yang ingin diukur oleh kuesioner tersebut. Suatu pernyataan/instrumen harus memiliki tingkat validitas tinggi jika ingin dianggap sebagai instrument yang valid. Koefisien validitas harus di atas koefisien tabel yaitu $\mathrm{r}_{\text {tabel }}=0,30$, sehingga lebih dapat diterima, apabila koefisien validitas kurang dari 0,30 dianggap tidak valid. Sehingga dapat disimpulkan jika pernyataan dianggap valid bila $r>0,30$ dan tidak valid apabila $r \leq 0,30$

\section{Uji Reliabilitas}

Yaitu menguji apakah hasil kuesioner mampu dipercaya atau tidak. Kuesioner dikata reliabel jika jawaban seseorang terhadap pertanyaan konsisten dari waktu ke waktu. Uji reliabel diperoleh dengan uji statistik Cronbach Alpha dengan kriteria:

Jika nilai alpha $>0,60$, intrumen reliabel dan bila nilai alpha $\leq 0,60$, instrumen dikatakan tidak reliabel

\section{Koefisien Korelasi Dan Determinasi}

Koefisien korelasi dilakukan untuk melihat besarnya keterikatan/ hubungan antara variabel bebas atas variabel terikatnya. Jika nilai $\mathrm{R}=0$ atau mendekati nilai 0 , maka hubungan antara variabel bebas dengan variabel terikatnya menunjukkan keterikatan yang lemah atau tidak sama sekali ada keterikatan, namun jika $\mathrm{R}=1$ atau mendekati nilai 1 maka keterikatan antara variabel bebas dengan variabel terikatnya sangat kuat dan hubungan yang terjadi adalah positif. Jika $R=-1$ atau mendekati -1 maka hubungan antara variabel bebas dan variabel terikat sangat kuat dan dikatakan hubungan yang terjadi adalah negatif. Sedangkan koefisien determinasi digunakan untuk mengetahui seberapa besar hubungan variabel bebas dengan varabel terikatnya dalam persamaan regresi, semakin besar koefisien determinasi semakin baik variabel bebas menjelaskan variabel terikat. Berikut rumus koefisien determinasi yaitu:

$\mathrm{KD}=\mathrm{r}^{2} \times 100 \%$

Keterangan :

$\mathrm{KD}=$ Koefisien Determinasi

$\mathrm{r}^{2}=$ Koefisien korelasi

\section{Regresi Berganda.}

Penelitian ini menggunakan teknik regresi linier berganda untuk mendeskripsikan/menggambarkan pengaruh variabel bebas atas variabel terikatnya. Model regresi berganda dinyatakan dalam rumus berikut:

$$
\begin{aligned}
& \hline \mathrm{Y}=\mathrm{a}+\mathrm{b}_{1} \mathrm{X}_{1}+\mathrm{b}_{2} \mathrm{X}_{2}+\mathrm{b}_{3} \mathrm{X}_{3}+\varepsilon \\
& \text { Keterangan } \\
& \mathrm{Y} \quad=\text { Keputusan Konsumen } \\
& \mathrm{a} \quad=\text { Konstanta } \\
& \mathrm{b}_{1}, \mathrm{~b}_{2}, \mathrm{~b}_{3}=\text { Koefisien regresi } \\
& \mathrm{X}_{1} \quad=\text { Promosi } \\
& \mathrm{X}_{2} \quad=\text { Periklanan } \\
& \mathrm{X}_{3} \quad=\text { Penjuaalan Personal } \\
& \varepsilon \quad=\text { Variabel Gangguan }
\end{aligned}
$$

\section{Uji Hipotesis}

Uji hipotesis dilakukan untuk menguji pengaruh variabel bebas atas variabel terikat secara parsial dan simultan yaitu :

\section{Uji F}

Uji $F$ dilakukan untuk mendeteksi apakah variabel bebas dalam model memiliki pengaruh bersama-sama/serentak kepada variabel terikat (Ghozali : 2013). Dalam penelitian ini uji hipotesis secara simultan/serentak dimaksudkan untuk mengukur besarnya pengaruh variabel bebas yaitu promosi, periklanan serta penjualan personal kepada variabel terikat (keputusan konsumen). Hipotesis yang akan diuji adalah :

$\mathrm{HO}=\mathrm{b}_{1} \quad \mathrm{~b}_{2} \quad \mathrm{~b}_{3}=0$ berarti tidak terdapat pengaruh signifikan antara promosi penjualan, periklanan serta penjualan personal secara bersama-sama kepada keputusan konsumen 
$\mathrm{H} 1=\mathrm{b}_{1} \quad \mathrm{~b}_{2} \quad \mathrm{~b}_{3} \neq 0$ artinya terdapat pengaruh signifikan antara promosi penjualan, periklanan serta penjualan personal secara bersama-sama kepada keputusan konsumen

Dasar keputusan (Ghozali : 2013) yaitu dengan melihat signifikansi yang diperoleh melalui perhitungan SPSS :

Bila tingkat signifikan $>0,05$ maka $\mathrm{H}_{0}$ diterima, $\mathrm{H}_{1}$ ditolak.

Jika tingkat signifikan $\leq 0,05$ maka $\mathrm{H}_{0}$ ditolak , $\mathrm{H}_{1}$ diterima

\section{$\mathbf{U j i}-\mathbf{t}$}

Uji-t digunakan untuk melihat apakah varibel bebas memiliki pengaruh secara parsial/masing-masing atas variabel terikatnya (Ghozali: 2013). Kriteria uji-t adalah:

$\mathrm{H}_{0}=\mathrm{b}_{1} \quad \mathrm{~b}_{2} \quad \mathrm{~b}_{3}=0$, artinya tidak terdapat pengaruh signifikan dari variabel promosi penjualan, periklanan serta penjualan personal secara parsial/masing-masing kepada keputusan konsumen

$\mathrm{H}_{0}=\mathrm{b}_{1} \quad \mathrm{~b}_{2} \quad \mathrm{~b}_{3} \neq 0$ artinya terdapat pengaruh signifikan dari variabel promosi penjualan, periklanan serta penjualan personal secara parsial/masing-masing kepada keputusan konsumen.

Untuk menguji hipotesis yaitu dengan cara melihat signifikansi yang diperoleh dengan bantuan SPSS. Jika signifikansi > 0,05 berarti $\mathrm{H}_{0}$ diterima dan $\mathrm{H}_{1}$ ditolak, dan jika tingkat signifikansi $\leq 0,05$, artinya $\mathrm{H}_{0}$ ditolak dan $\mathrm{H}_{1}$ diterima.

\section{HASIL PEMBAHASAN}

\section{Karakteristik Konsumen}

Uji data secara deskriptif, menguraikan hasil tanggapan terhadap 100 responden yaitu : karakteristik konsumen menginap mayoritas adalah laki-laki sebesar $61 \%$, hal ini dikarena untuk menghilangkan kepenatan setelah melakukan aktivitas sehari-hari dalam bekerja, $41 \%$ mayoritas konsumen berusia 31-40 tahun, menunjukkan bahwa konsumen menginap adalah orang dewasa , memiliki penghasilan tetap, mayoritas pendidikan terakhir $58 \%$ adalah sarjana, sehingga memiliki kematangan berpikir untuk menggunakan jasa perhotelan. 55\% konsumen adalah pegawai swasta, memiliki penghasilan yang menunjukkan kemampuan untuk menggunakan jasa penginapan. Sebanyak $37 \%$ mayoritas konsumen memiliki rata-rata pendapatan $\mathrm{Rp}$ 4.100.000Rp 5.000.000/bulan.

\section{Tanggapan Responden Berkaitan Dengan Promosi Penjualan}

Grand Cempaka melakukan promosi penjualan dengan cara memberikan special diskon kepada konsumen PNS sebesar 60\%, diskon paket anak sekolah, gathering package, family tour, dan memberikan potongan harga untuk konsumen pengguna kartu kredit bank tertentu, serta memberikan berbagai macam undian kepada konsumen (diskon tambahan, gratis wisata ke Kebun Raya, Taman Matahari dan Taman Safari Indonesia). Promosi tersebut dilakukan untuk membujuk dan mempengaruhi, memberikan informasi berkaitan dengan produk perusahaan kepada konsumen sasaran agar berminat untuk menginap.

Tabel 3. Rekapitulasi Penilaian Responden Terhadap Promosi Penjualan

\begin{tabular}{clcc}
\hline $\mathrm{N}_{0}$ & \multicolumn{1}{c}{ Traian } & Penilaian Kousumen & Keterangan \\
\hline 1 & Penberian diskon & 3,80 & Baik \\
2 & Besarvya diskon yang diberikn & 3,59 & Baik \\
3 & Penberian modian & 3,59 & Baik \\
4 & Jenis undian yang diberikn & 3,46 & Baik \\
\hline Rata-rata Penilaian Konsumen terhadap & 3,01 & Baik \\
\hline
\end{tabular}

Sumber: Data Primer, 2017. (Diolah).

Tabel 3 merupakan rekapitulasi penilaian rata-rata responden terhadap promosi penjualan, dengan nilai mean sebesar $3,61 \%$ (kategori baik). Hal tersebut memperlihatkan bahwa Grand Cempaka Cipayung-Bogor sudah memberikan diskon yang cukup kompetitif dan besarnya diskon serta jenis undian yang diberikan cukup menarik perhatian konsumen. 


\section{Tanggapan Responden Berkaiatan Dengan Periklanan}

Grand Cempaka melakukan periklanan melalui publikasi dimedia cetak (brosur dan selebaran), media elektronik (website), dan menggunakan media di luar ruangan (papan reklame/iklan dipinggir jalan dan pintu masuk hotel).

Tabel 4. Rekapitulasi Penilaian Responden Terhadap Periklanan

\begin{tabular}{|c|c|c|c|}
\hline $\mathrm{N}_{0}$ & Train & Penilaian Koasumen & Keteragna \\
\hline 1 & $\begin{array}{l}\text { Informasi dan meda cetrik yong } \\
\text { fpublikaskn }\end{array}$ & 438 & Sungat Baik \\
\hline 2 & $\begin{array}{l}\text { Infomasi dan media elobtrol } \\
\text { yang dypublisolon }\end{array}$ & 4,46 & Sangat Beik \\
\hline 3 & 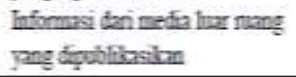 & 423 & Sengat Baik \\
\hline & $\begin{array}{l}\text { ara-rata Penilain Keasamen } \\
\text { terhadap Perikhnan (Xs) }\end{array}$ & 4,36 & Sangit Buik \\
\hline
\end{tabular}

Tabel 4 merupakan rekapitulasi penilaian rata-rata responden terhadap periklanan, dengan nilai mean sebesar 4,36 (kategori sangat baik). Hal tersebut memperlihatkan bahwa informasi yang disampaikan perusahaan melalui media cetak, media elektronik serta media diluar ruangan cukup mendorong keinginan konsumen untuk menginap.

\section{Tanggapan Responden Berkaitan Dengan Penjualan Personal}

Grand Cempaka melalui tenaga pemasarannya melakukan penjualan personal dengan cara mendatangi individu dan perusahaan-perusahaan secara langsung untuk menawarkan jasa perhotelan.

Tabel 5. Rekapitulasi Penilaian Responden Terhadap Penjualan Personal

\begin{tabular}{|c|c|c|c|}
\hline $\mathrm{N}_{\mathrm{e}}$ & Trains & Penilhinn Kensumen & Keteragne \\
\hline & 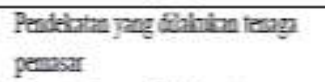 & 3,74 & $\mathrm{Baz}$ \\
\hline 2 & $\begin{array}{l}\text { Presensi yng dalmbas temgn } \\
\text { permesr }\end{array}$ & 3,51 & $\mathrm{Bez}$ \\
\hline 3 & $\begin{array}{l}\text { Mengrbi lirberatur yang dhin in } \\
\text { tenga pemase }\end{array}$ & 3,41 & $\mathrm{Baz}$ \\
\hline 4 & $\begin{array}{l}\text { Kesepalatn yang dibinkn tengn } \\
\text { pempsar }\end{array}$ & 3,74 & $\mathrm{Baz}$ \\
\hline & $\begin{array}{l}\text { Rata-raca Penlaian Kansumen } \\
\text { terhadap Peajoban Personal (X) }\end{array}$ & 3,60 & $\mathrm{Br}$ 政 \\
\hline
\end{tabular}

Tabel 5 merupakan rekapitulasi penilaian rata-rata responden terhadap penjualan personal dengan nilai mean sebesar 3,60 (kategori baik). Hal tersebut memperlihatkan bahwa tenaga pemasar perusahaan memiliki kompetensi untuk memberikan informasi jasa perhotelan kepada konsumen sasaran dengan baik, menanggapi keluhan pelanggan, memiliki kemampuan memotivasi pelanggan kearah kesepakatan untuk menginap .

\section{Tanggapan Responden Berkaitan Dengan Keputusan Konsumen}

Keputusan konsumen merupakan tahapan yang dilalui oleh konsumen sebelum melakukan keputusan untuk pembelian/melakukan transaksi .

Tabel 6. Rekapitulasi Penilaian Responden Terhadap Keputusan Konsumen

\begin{tabular}{|c|c|c|c|}
\hline $\mathbf{V}_{0}$ & Trins & $\begin{array}{l}\text { Pelibin } \\
\text { Kencumea }\end{array}$ & Setrangu \\
\hline 1 & Tescsuin abakefotim & 372 & Bat \\
\hline 2 & Terselapg verbgi falits & 39 & Bay \\
\hline 3 & Pebeim iffones & 3,72 & Bat \\
\hline 4 & 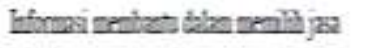 & 3,79 & Bat \\
\hline 5 & 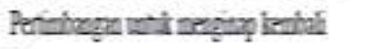 & $3: 29$ & Bat \\
\hline 6 & Kephasen yontept & 3,78 & Bat \\
\hline 7 & 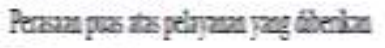 & $3 \pi / 2$ & Bat \\
\hline 8 & Perthondain & 3,81 & Bat \\
\hline & 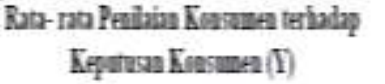 & 3,8 & Buil \\
\hline
\end{tabular}

Tabel 6 merupakan rekapitulasi penilaian rata-rata responden mengenai keputusan konsumen dengan nilai mean 3,80 (kategori baik). Hal tersebut memperlihatkan bahwa harapan konsumen terpenuhi sehingga memberikan keamanan dan kenyamanan selama menginap, pemberian informasi sangat membantu konsumen untuk memilih jasa perhotelan. Kepuasan terhadap pelayanan dan berbagai fasilitas memberikan pertimbangana konsumen untuk menginap. 


\section{Uji Validitas}

Uji validitas terhadap item-iem pernyataan kuesioner yaitu dengan menghitung koefisien korelasi dari tiap-tiap penyataan dengan skor total yang diperoleh, dibandingkan dengan angka $r$ product moment.

\begin{tabular}{|c|c|c|c|}
\hline Variabel & Indikator & Corelation $\left(\mathrm{r}_{\text {binas }}\right)$ & Keterangan \\
\hline \multirow{4}{*}{ Promosi Penjualan $\left(\mathrm{X}_{1}\right)$} & $\mathrm{X}_{1} \cdot 1 \mathrm{a}$ & 0,641 & Valid \\
\hline & $\mathrm{X}_{1} .1 \mathrm{~b}$ & 0,623 & Valid \\
\hline & $\mathrm{X}_{1} .2 \mathrm{a}$ & 0,645 & Valid \\
\hline & $\mathrm{X}_{1} \cdot 2 \mathrm{~b}$ & 0,607 & Valid \\
\hline \multirow{3}{*}{ Periklanan $\left(\mathrm{X}_{2}\right)$} & $\mathrm{X}_{2} \cdot 1$ & 0,775 & Valid \\
\hline & $\mathrm{X}_{2} .2$ & 0,730 & Valid \\
\hline & $\mathrm{X}_{2} .3$ & 0,780 & Valid \\
\hline \multirow{4}{*}{ Penjualan Personal $\left(\mathrm{X}_{\mathrm{j}}\right)$} & $\mathrm{X}_{\mathrm{3} .1}$ & 0,701 & Valid \\
\hline & $\mathrm{X}_{3} .2$ & 0,672 & Valid \\
\hline & $\mathrm{X}_{\mathrm{3}} .3$ & 0,717 & Valid \\
\hline & $\mathrm{X}_{3} .4$ & 0,646 & Valid \\
\hline \multirow{8}{*}{ Keputusan Konsumen (Y) } & $Y_{1} .1$ & 0,762 & Valid \\
\hline & $Y_{1}, 2$ & 0,703 & Valid \\
\hline & $\mathrm{Y}_{2} .1$ & 0,678 & Valid \\
\hline & $\mathrm{Y}_{2} .2$ & 0,617 & Valid \\
\hline & $\mathrm{Y}_{3}$ & 0,637 & Valid \\
\hline & $\mathrm{Y}_{4}$ & 0,713 & Valid \\
\hline & $Y_{s}, 1$ & 0,677 & Valid \\
\hline & $\mathrm{Y}_{\mathrm{g}} 2$ & 0,555 & Valid \\
\hline
\end{tabular}

Sumber : Data Primer, 2017 (Diolah)

Tabel 7 menunjukkan semua item pernyataan memiliki $r_{\text {hasil }}>r_{\text {tabel }}$, dan sesuai dengan ketentuan yang sudah ditetapkan, maka semua item pernyataan valid dan memungkinkan untuk dipergunakan dalam penelitian.

\section{Uji Reliabilitas}

Instrumen kuesioner dikatakan reliabel/handal jika jawaban responden atas pertanyaan konsisten dari waktu ke waktu.

Tabel 8. Uji Reliabilitas

\begin{tabular}{|lc:c|}
\hline \multicolumn{1}{|c}{ Variabel } & Nilai $(\alpha)$ & Keterangan \\
\hline PromosiPenjualan $\left(\mathrm{X}_{1}\right)$ & 0,740 & Reliabel \\
Periklana $\left(\mathrm{X}_{2}\right)$ & 0,808 & Reliabel \\
Penjualan Personal $\left(\mathrm{X}_{3}\right)$ & 0,771 & Reliabel \\
Keputusan Konsumen $(\mathrm{Y})$ & 0,765 & Reliabel \\
\hline
\end{tabular}

Sumber : Data diolah, 2017.

Dari hasil uji reliabilitas cronbach alpha lebih besar dari 0,60, artinya butir pernyataan dari variabel penelitian, seluruhnya memungkinkan dipergunakan dalam penelitian.

\section{Uji F}

Uji $F$ dilakukan untuk menganalisis variabel yang diteliti yaitu promosi, periklanan serta penjualan personal layak/ tidak digunakan dalam model penelitian. . Hasil pengujian dengan uji $\mathrm{F}$ adalah:

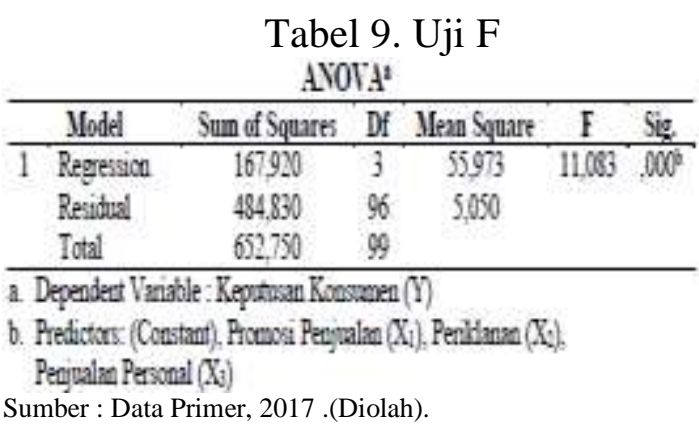

Berdasarkan tabel 9, tingkat signifikan uji $\mathrm{F}=0,000<0,05$ (level of signifikan), yang mengisyaratkan bahwa pengaruh variabel independen yaitu promosi, periklanan, dan penjualan personal secara bersama-sama (simultan) memiliki pengaruh kepada keputusan konsumen. Hal tersebut menginsyaratkan model penelitian layak dilanjutkan pada analisa selanjutnya

\section{Koefisien Korelasi (R) dan Koefisien Determinasi $\left(\mathbf{R}^{2}\right)$}

Koefisien determinasi digunakan untuk mengetahui besarnya persentase kontribusi variabel bebas bersama-sama berpengaruh signifikan kepada keputusan konsumen pelanggan Grand Cempaka. Hasil perhitungan dapat dilihat pada tabel berikut:

Tabel 10. Uji Korelasi dan Koefisien Determinasi Yldelemman'

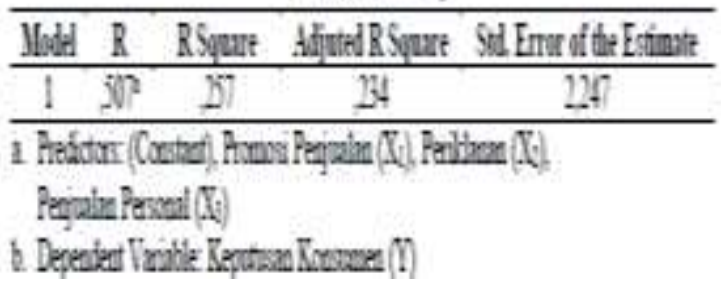

Sumber: Data Primer, 2017 (Diolah) 
Tabel 10 memperlihatkan hasil koefisien korelasi $\mathrm{R}$ adalah sebesar 0,507 atau $50,7 \%$, artinya hubungan antara promosi, periklanan serta penjualan personal kepada keputusan konsumen memiliki hubungan sedang .

Besarnya nilai $\mathrm{R}$ square $\left(\mathrm{R}^{2}\right)$ adalah 0,257 artinya kontribusi dari variabel promosi, periklanan serta penjualan personal secara bersama-sama/simultan kepada keputusan konsumen sebesar 25,7 \%, sisanya sebesar $74,3 \%$ dikontribusi oleh faktor lain.

\section{Regresi Linier Berganda}

Regresi linier berganda dilakukan untuk melihat besarnya pengaruh faktor dalam model penelitian yaitu promosi penjualan, periklanan, serta penjualan personal kepada keputusan konsumen secara linier .

\begin{tabular}{|c|c|c|c|c|c|c|}
\hline \multicolumn{7}{|c|}{$\begin{array}{c}\text { Tabel 11. Koefisien Regresi } \\
\text { Coefficinat }\end{array}$} \\
\hline \multirow{2}{*}{\multicolumn{2}{|c|}{$\mathrm{I}_{0}$}} & \multicolumn{2}{|c|}{$\begin{array}{l}\text { Trstandardined } \\
\text { Cefficients }\end{array}$} & \multirow{2}{*}{$\begin{array}{l}\begin{array}{c}\text { Standiardized } \\
\text { Cefficiturs }\end{array} \\
\text { Betha }\end{array}$} & \multirow[b]{2}{*}{$\mathrm{T}$} & \multirow[b]{2}{*}{ Sig } \\
\hline & & B & Std Error & & & \\
\hline \multirow[t]{4}{*}{1} & (Constant) & 9,607 & 3,669 & & 2618 & 010 \\
\hline & Promsi Pergalon $\left(X_{1}\right)$ & 663 & 164 & .356 & 4028 & 000 \\
\hline & Perildanen $\left(X_{i}\right)$ & .517 & 175 & .361 & 2954 &, 04 \\
\hline & Peguain Pescal $\left(X_{2}\right)$ & 306 & 14] & 191 & 2171 & 032 \\
\hline
\end{tabular}

Berikut ini hasil perhitungan berdasarkan analisis linier berganda :

$$
Y=9,607+0,663 X_{1}+0,517 X_{2}+0,306 X_{3}+\varepsilon
$$

Berdasarkan persamaan tersebut maka diketahui nilai konstanta (a) sebesar 9,607, artinya saat promosi, periklanan serta penjualan personal nol $\left(\mathrm{X}_{1}, \mathrm{X}_{2}, \mathrm{X}_{3}=0\right)$ maka keputusan konsumen 906,7 \% . Koefisien regresi promosi penjualan $=0,663$, artinya setiap peningkatan implementasi pelaksanaan promosi penjualan, diduga akan menaikkan keputusan konsumen menginap. Koefisien regresi periklanan $=0,517$, artinya setiap mengalami peningkatan periklanan maka diduga akan diikuti oleh kenaikan keputusan konsumen menginap. Koefisien regresi penjualan personal $=0,306$ artinya setiap mengalami peningkatan penjualan personal diduga akan menaikkan keputusan konsumen menginp di Grand Cempaka Cipayung-Bogor.

Faktor yang memiliki pengaruh dominan kepada keputusan konsumen terdapat pada perhitungan koefisien pada model persamaan regresi di atas. Dapat disimpulkan promosi penjualan $\left(\mathrm{X}_{1}\right)$ memiliki koefisien regresi paling besar yaitu 0,663 , artinya yang memiliki pengaruh sangat kuat kepada keputusan konsumen yaitu promosi penjualan..

\section{Uji Hipotesis (Uji-t)}

Rekapitulasi uji-t adalah sebagai berikut:

Tabel 12. Rekapitulasi Hasil Uji-t

\begin{tabular}{|c|c|c|c|c|}
\hline Do & Trinbel. & lariabelI & Hall & Pengani \\
\hline 1 & Proaki Pejulan & Beptixina Tossumen & 4,08161601 & Posifidua Simifican \\
\hline ? & Perillon & Reptivin Rosomen & 20541661 & Positidan Simificon \\
\hline 3 & Penalan Persed & Beptivan Rossuren & $2171 \mathrm{D} 1661$ & Positiduan Simificn \\
\hline
\end{tabular}

Tabel 12 menjelaskan :

a) Pengaruh promosi penjualan dengan keputusan konsumen diperoleh perhitungan dengan nilai $t_{\text {hitung }}=4,028$ dan nilai $\mathrm{t}_{\text {tabel }}$ untuk $\alpha=0,05$, derajat kebebasan 100-3-1= 96 sebesar 1,661 , artinya $t_{\text {hitung }}>t_{\text {tabel }}(4,028>1,661)$, artinya $\mathrm{H}_{0}$ ditolak, diterimanya $\mathrm{H}_{\mathrm{a}}$, artinya pengaruh promosi penjualan kepada keputusan konsumen adalah positif dan signifikan.

b) Pengaruh periklanan kepada keputusan konsumen diperoleh perhitungan dengan nilai $\mathrm{t}_{\text {hitung }}=2,954$ dan nilai $\mathrm{t}_{\text {tabel }}$ untuk $\alpha$ $=0,05$, derajat kebebasan 100-3-1=96 sebesar 1,661 berarti $t_{\text {hitung }}>t_{\text {tabel }}(2,954$ $>1,661)$ sehingga $\mathrm{H}_{0}$ ditolak, diterimanya $\mathrm{H}_{\mathrm{a}}$, artinya pengaruh periklanan kepada keputusan konsumen adalah positif dan signifikan.

c) Pengaruh penjualan personal kepada keputusan konsumen diperoleh perhitungan nilai $t_{\text {hitung }}=2,171$ dan nilai $\mathrm{t}_{\text {tabel }}$ untuk $\alpha=0,05$, derajat kebebasan 
100-3-1=96 sebesar 1,661 berarti $t_{\text {hitung }}>$ $\mathrm{t}_{\text {tabel }}\left(2171>1,661\right.$ sehingga $\mathrm{H}_{0}$ ditolak, diterimanya $\mathrm{H}_{a}$, artinya pengaruh penjualan personal kepada keputusan konsumen adalah positif dan signifikan.

\section{KESIMPULAN DAN IMPLIKASI}

Kesimpulan penelitian yakni:

1. Grand Cempaka melakukan bauran promosi yaitu :

a) Promosi penjualan dilakukan dengan memberikan diskon serta undian kepada konsumen.

b) Periklanan dilakukan melalui publikasi informasi perusahaan melalui penggunaan media cetak, media elektronik serta media luar ruangan.

c) Penjualan personal dilakukan melalui kunjungan tenaga pemasar untuk melakukan penawaran jasa perhotelan kepada individu dan perusahaanperusahaan melalui tatap muka.

2. Penilaian responden terhadap pelaksanaan promosi penjualan, periklanan serta penjualan personal di Grand Cempaka yaitu :

a) Promosi penjualan melalui pemberian diskon maupun undian mendapat penilaian kategori baik.

b) Periklanan melalui media cetak (brosur, selebaran), media elektronik (internet dan website) serta penggunaan media diluar ruangan (reklame / papan iklan) mendapat penilaian kategori paling baik .

c) Penjualan personal yang dilakukan tenaga pemasar melalui presentasi, memiliki kemampuan mengatasi keberatan/keluhan pelanggan, dan dapat memotivasi konsumen kearah kesepakatan mendapat penilaian kategori baik.

3. Uji F memperlihatkan bahwa promosi penjualan, periklanan serta penjualan personal mempunyai pengaruh yang positif serta signifikan secara simultan/serentak terhadap keputusan konsumen.

4. Uji-t menunjukkan bahwa :

a) Promosi penjualan mempunyai pengaruh yang positif serta siginifikan secara parsial kepada keputusan konsumen .

b) Periklanan mempunyai pengaruh yang positif serta signifikan secara parsial kepada keputusan konsumen.

c) Penjualan personal mempunyai pengaruh yang positif serta signifikan secara parsial kepada keputusan konsumen .

Implikasi penelitian adalah :

1. Strategi bauran promosi harus dievaluasi, dipertahankan serta ditingkatkan karena berpengaruh terhadap perilaku pelanggan terhadap keputusan menginap.

2. Fasilitas dan pelayanan harus ditingkatkan sehingga memberikan nilai pelanggan untuk dijadikan keunggulan kompetitif di arena persaingan dengan perusahaan sejenis .

3. Meningkatkan kemampuan tenaga marketing melalui pendidikan dan pelatihan sehingga pengetahuan, keterampilan serta attitude tenaga pemasar meningkat.

\section{UCAPAN TERIMKASIH}

Ucapan terima kasih kepada Grand Cempaka Resort and Convention CipayungBogor dan responden yang berpartisipasi untuk menjawab dan mengisi kuesioner penelitian.

\section{DAFTAR PUSTAKA}

Alma, Buchari, 2013. Manajemen Pemasaran dan Pemasaran Jasa, Bandung: Alfabeta.

Basuki, Agus Tri dan Nano Prawoto, 2016. Analisis Regresi Dalam Penelitian 
Ekonomi Dan Bisnis, Jilid 1, Jakarta: Rajawali Pers.

Darmesta, Basu Swastha, 2002. Manajemen Pemasaran, Edisi Kedua, Cetakan Kedelapan, Jakarta:Liberty.

Ferdinand, Augusty, 2005. Manajemen Pemasaran: Sebuah Pendekatan Strategi Research Paper Series No.1, Program Magister Manajemen Undip, Semarang: Badan Penerbit Undip.

Ghozali, Imam, 2013. Aplikasi Analisis Multivariete Dengan Program SPSS, Edisi ketujuh, Semarang: Badan Penerbit, Universitas Diponogoro.

Kotler, Philip, 2012, Manajemen Pemasaran, Edisi Milenium, Jakarta: PT.Prehallindo.

Gary Armstrong, 2009. Prinsip-Prinsip Pemasaran, Edisi 12 Jilid 1,Jakarta: Erlangga ,

Kevin Lane Keller, 2009. Manajemen Pemasaran, Edisi 13, Jilid 1, Jakarta: Yogyakarta:Erlangga .

Priyatno, Duwi, 2013. Analisis Korelasi Regresi dan Multivarite Dengan SPSS, Gava Media.

Purwanto, Bambang dan Rina Sutha Hayu, 2014, Pengaruh Periklanan dan Promosi Penjualan Terhadap keputusan Pembelian Konsumen Di Supermarket Hypermart, Skripsi, Fakultas Ekonomi, Universitas Bengkulu.

Safitri, Yuestha Dina, 2008. Pengaruh Periklanan dan Promosi Penjualan Terhadap Keputusan Pembelian Di Distro Eat 347 Malang, Skripsi, fakultas Ekonomi, Universitas Negeri Malang.

Saladin, Djaslim, 2003. Manajemen Pemasaran (Analisis, Perencanaan, Pelaksanaan Dan Pengendalian), Bandung: Linda Karya.

Sugiono, 2015. Metode Penelitian Kuantitatif, Kualitatif Dan R\&D, Bandung:Alfabeta. 2015. Statistika Untuk Penelitian, Bandung:Alfabeta.
Tjiptono, Fandy, 2008. Strategi Pemasaran, Edisis 3. Yogyakarta : Andi. ,2014. Pemasaran Jasa, Edisi 1,Bandung: Andi, 